\title{
Modul Matematika Berdasarkan Model Pembelajaran Problem Based Learning Materi Pokok Trigonometri
}

\author{
Nia Anggraini' ${ }^{1}$, Rubhan Masykur $^{2}$ \\ ${ }_{1}^{1}$ Bimbel Prestasi, Jalan Endro Suratmin, Sukarame, Bandar Lampung 35133, Indonesia \\ ${ }^{2}$ Universitas Islam Negeri Raden Intan Lampung, Jalan Endro Suratmin, Sukarame, Bandar \\ Lampung 35133, Indonesia \\ *Corresponding Author. E-mail: niaanggraini170217@gmail.com
}

Received : 28-05-2018; Revised : 30-05-2018; Accepted : 31-05-2018

\begin{abstract}
Abstrak
Tujuan dari penelitian ini adalah mengembangkan Modul matematika berdasarkan model pembelajaran PBL (Problem Based Learning) materi pokok trigonometri untuk SMA. Dalam penelitian ini menggunakan metode penelitian dan pengembangan R\&D (Research and Development) Borg and Gall yang dimodifikasi dari sugiyono, adapun prosedur yang digunakan sebagai berikut: (1) potensi dan masalah, (2) mengumpulkan informasi, (3) desain produk, (4) validasi desain, (5) perbaikan desain, (6) uji coba produk, (7) revisi produk. Teknik pengumpulan data yang digunakan adalah wawancara, angket, observasi, dan dokumen.Validasi dilakukan oleh ahli materi, ahli media dan ahli bahasa.Uji coba dilakukan melalui dua tahap yaitu uji coba kelompok kecil dan uji coba lapangan.Hasil validasi ahli materi, ahli media, dan ahli bahasa diperoleh nilai rata-rata dengan kriteria valid. Pada uji coba lapangan guna mengetahui respon peserta didik di MA Muhammadiyah Bandar Lampung, SMA AL-AZHAR 3, dan SMA Muhammadiyah 2 Bandar Lampung memperoleh skor rata-rata sebesar 3,58 dengan kriteria sangat menarik.
\end{abstract}

Kata Kunci : Modul, PBL, Trigonometri.

\begin{abstract}
The purpose of this study is to develop a mathematic module based on Problem Based Learning method trigonometry lessons for Senior High School. In this study use R\&D (Research and Development) Borg and Gall modified from sugiyono, the procedure used as follows: (1) potential and problems, (2) data collection, (3) product design, (4) product validation, (5) product revision, (6) product trial, (7) product revision. Data collection techniques used areinterview, kuisioner, observation, and document. Validaton is done by material experts, media experts, and linguists. Trials are conducted through two stages is small group trials and field trials. Validation results material experts, media experts, and linguists obtained the average value with valid criteria. On field trials determine the response of learners in Senior High School Muhammadiyah 2 Bandar Lampung, in Senior High School AL-AZHAR 3, and in Senior High School Muhammadiyah 2 Bandar Lampung obtained average value of 3,58 with criteria very interesting.
\end{abstract}

Keywords: Module, PBL, Trigonometry.

\section{PENDAHULUAN}

Matematika merupakan salah satu mata pelajaran yang wajib dilaksanakan pada setiap jenjang pendidikan mulai dari sekolah dasar sampai perguruan tinggi (Sulistyaningrum, Karyanto, \& Sunarno, 2015). Maka dari itu, hal tersebut menunjukkan bahwa matematika memiliki peranan penting bagi dunia pendidikan dan perkembangan teknologi (Syahrir \& Susilawati, 2015).Bertolak belakang dengan peran penting matematika, faktanya masih banyak siswa yang menganggap matematika adalah pelajaran yang sulit (Nurwani, Rizki Wahyu Yunian Putra, Fredi Ganda Putra, 2017). Terbukti dengan hasil study kasus yang dilakukan penulis bahwa 
banyak siswa yang tidak suka dengan mata pelajaran matematika, salah satu faktor yang berpengaruh adalah bahan ajar, media dan pemakaian metode yang digunakan guru kurang membawa peserta didik untuk terlibat langsung dalam pembelajaran. Peserta didik mengiginkan sebuah bahan ajar yang berbeda, bahan ajar yang menarik dan bisa membuat peserta didik lebih termotivasi dan lebih aktif dalam mengikuti proses pembelajaran.

Berdasarkan penelitian terdahulu yang berkaitan tentang pengembangan modul antara lain: Dalam penelitian Syahrir dan Susilawati (2015) yang berjudul "Pengembangan Modul Pembelajaran Matematika Siswa SMP", perbedaan penelitian syahrir dengan penelitian ini adalah pada penelitian Syahrir dan Susilawati pengembangan modul dilakukan untuk siswa SMP, sedangkan pada penelitian ini pengembangan modul dilakukan untuk siswa SMA. Penelitian Wenno (2014) yang berjudul "Pengembangan Modul IPA Berbasis Problem Solving Method Berdasarkan Karakteristik Siswa dalam Pembelajaran di SMP/MTs", perbedaan penelitian Wenno dengan penelitian ini adalah pada penelitian Izaak $\mathrm{H}$. Wenno pengembangan modul IPA menggunakan Pendekatan Problem Solving Method, sedangkan pada penelitian ini pengembangan modul Matematika menggunakan metode Problem Based Learning. Penelitian Rhosyida dan Jailani (2014) yang berjudul "Pengembangan Modul Matematika SMK Bidang Seni, Kerajinan, dan Pariwisata Berbasis OpenEnded Problem Sebagai Implementasi KTSP", perbedaan penelitian Rhosyida dan Jailani dengan penelitian penulis adalah pada penelitian Rhosyida dan Jailani Pengembangan modul matematika menggunakan pendekatan Open-Ended Problem, sedangkan pada penelitian ini pengembangan modul matematika menggunakan pendekatan Problem Based Learning.

Berdasar penelitian terdahulu tentang pengembangan yang menggunakan metode Problem Based Learning antara lain: Penelitian Khayati, Sujadi, dan Sari Suprapto (2016) yang berjudul "Pengembangan Modul Matematika untuk Pembelajaran Berbasis Masalah (Problem Based Learning) pada Materi Pokok Persamaan Garis Lurus Kelas VIII SMP", perbedaan penelitian Khayati, Sujadi, dan Sari Suprapto dengan penelitian penulis adalah pada penelitian Khayati, Sujadi, dan Sari Suprapto pengembangan modul matematika berbasis PBL pada materi persamaan garis lurus siswa SMP, sedangkan pada penelitian ini pengembangan modul berdasarkan PBL pada materi trigonometri siswa SMA. Penelitian Citroresmi, Sugiatno, dan Suratman (2016) yang berjudul "Pengembangan Modul Matematika Berbasis Masalah untuk Meningkatkan Kemampuan Penyelesaian Masalah dan Berpikir Kreatif Matematis Siswa", perbedaan penelitian tersebut dengan penelitian ini adalah pada penelitian Citroresmi, Sugiatno, dan Suratman bertujuan untuk meningkatkan kemampuan penyelesaian masalah dan berpikir matematis, sedangkan pada penelitian ini bertujuan untuk mengetahui respon siswa pada modul yang dikembangkan. Penelitian Nurhayati, Widodo, dan Soesilowati (2015) yang berjudul "Pengembangan LKS Berbasis Problem Based Learning 
Pokok Bahasan Tahap Pencatatan Akutansi Perusahaan Jasa", Perbedaan Penelitian tersebut dengan penelitian penulis adalah pada penelitian Nurhayati, Widodo, dan Soesilowati mengembangkan LKS Berbasis PBL pencatatan akutansi, sedangkan penelitian ini mengembangkan modul berdasarkan PBL materi trigonometri.

Berdasar penelitian terdahulu tentang pengembangan pada materi trigonometri antara lain: Penelitian Semadiartha (2014) yang berjudul "Pengembangan Media Pembelajaran Berbasis Komputer dengan Microsoft Excel yang Berorientasi Teori Van Hiele pada Bahasan Trigonometri Kelas X SMA untuk Meningkatkan Prestasi dan Motivasi Belajar Matematika Siswa", perbedaan penelitian tersebut dengan penelitian ini adalah pada penelitian Semadiartha mengembangkan media pembelajaran berbasis komputer, sedangkan penelitian ini mengembangkan modul matematika berdasarkan PBL materi trigonometri. Penelitian Syarifah (2017) yang berjudul "Pengembangan LKPD Berorientasi Nilainilai Islam Melalui Pendekatan Inkuiri Terbimbing Materi Trigonometri", perbedaan penelitian tersebut dengan penelitian penulis adalah pada penelitian Syarifah mengembangkan LKPD dengan Pendekatan Ikuiri Terbimbing, sedangkan pada penelitian ini mengembangkan modul dengan model pembelajaran PBL. Penelitian Putra dan Anggraini (2016) yang berjudul "Pengembangan Bahan Ajar Materi Trigonometri Berbantuan Software ImindMap", perbedaan penelitian tersebut dengan penelitian penulis adalah pada penelitian Putra dan Anggraini menggunakan bantuan software ImindMap, sedangkan pada penelitian ini pengembangan modul dengan model pembelajaran PBL.

Keterbaharuan dari penelitian ini yaitu penulis akan mengembangkan Modul Matematika Berdasarkan Model Pembelajaran Problem Based Learning Materi Pokok Trigonometri untuk SMA, dimana contoh masalah yang dituangkan terintegrasi dengan nilai-nilai islami.

\section{METODE}

Dalam Penelitian ini menggunakan metode penelitian dan pengembangan (Research and Development).Model pengembangan penelitian ini yaitu model Borg and Gall yang dimodifikasi dari Sugiyono (2012) yang meliputi:

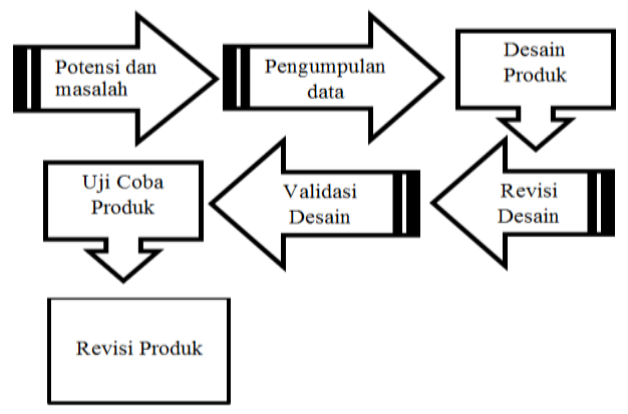

Gambar 1. Langkah-langkah penggunaan metode research and development

Adapun sistematika dari metode penelitian dan pengembangan Modul Matematika Berdasarkan Model Pembelajaran PBL adalah sebagai berikut: Potensi dan masalah, mengumpulkan informasi, desain produk, validasi desain, perbaikan desain, uji coba produk, revisi produk.

Tabel 1. Skor Validasi Ahli (dimodifikasi)

\begin{tabular}{cc} 
Skor & $\begin{array}{c}\text { Pilihan Jawaban } \\
\text { Kelayakan }\end{array}$ \\
4 & Sangat Baik \\
3 & Baik \\
2 & Kurang Baik \\
1 & Sangat Kurang Baik \\
\hline
\end{tabular}


Selanjutnya data hasil perolehan skor dicari rata-ratanya dengan menggunakan rumus berikut:

Dengan:

$$
\bar{x}=\frac{\sum_{i=1}^{n} x_{i}}{n}
$$

$$
\mathrm{X}_{\mathrm{i}}=\frac{\text { jumlah } \text { skor }}{\text { skor maks }} \times 4
$$

Keterangan : $\bar{x}=$ rata - rata akhir

$$
\begin{aligned}
& x_{i}=\quad \text { nilai } \\
& \text { operasionalangket } \\
& \text { peserta didik } \\
& n=\text { banyaknya aspek butir } \\
& \text { soal }
\end{aligned}
$$

Kemudian hasil angket yang diperoleh dari validasi ahli dikategorikan sesuai dengan interpretasi pada tabel berikut ini:

Tabel 2. Kriteria Validasi (dimodifikasi)

\begin{tabular}{ccc} 
Skor Kualitas & $\begin{array}{c}\text { Kriteria } \\
\text { Kelayak } \\
\text { an }\end{array}$ & Keterangan \\
$3,26<\overline{\mathrm{x}} \leq 4,00$ & Valid & Tidak Revisi \\
$2,51<\overline{\mathrm{x}} \leq 3,26$ & $\begin{array}{c}\text { Cukup } \\
\text { Valid }\end{array}$ & $\begin{array}{c}\text { Revisi } \\
\text { Sebagian }\end{array}$ \\
$1,76<\overline{\mathrm{x}} \leq 2,51$ & $\begin{array}{c}\text { Kurang } \\
\text { Valid }\end{array}$ & $\begin{array}{c}\text { Revisi sebagian \& } \\
\text { pengkian ulang } \\
\text { materi }\end{array}$ \\
& Tidak & Revisi Total \\
& Valid & \\
\hline
\end{tabular}

Sedangkan hasil angket yang diperoleh dari peserta didik dan pendidik disesuaikan dengan tebel interpretasi berikut:

\section{Tabel 3. Kriteria Validasi (dimodifikasi)}

\begin{tabular}{cc}
\hline Skor Kualitas & $\begin{array}{c}\text { Pertanyaan Kualitas } \\
\text { Aspek Kemenarikan }\end{array}$ \\
$3,26<\overline{\mathrm{x}} \leq 4,00$ & Sangat Menarik \\
$2,51<\overline{\mathrm{x}} \leq 3,26$ & Menarik \\
$1,76<\overline{\mathrm{x}} \leq 2,51$ & Kurang Menarik \\
$1,00<\overline{\mathrm{x}} \leq 1,76$ & Sangat kurang Menarik \\
\hline
\end{tabular}

Produk pengembangan akan berakhir saat skor penilaian terhadap modul ini telah memenuhi syarat kelayakan dengan tingkat kesesuaian materi dan desain, dikategorikan sangat menarik atau manarik.

\section{HASIL DAN PEMBAHASAN}

Hasil utama dari penelitian dan pengembangan ini adalah Modul Matematika Berdasarkan Model Pembelajaran PBL (Problem Based Learning) Pokok Materi Trigonometri untuk SMA. Hasil validasi uji kelayakan oleh beberapa validator adalah sebagai berikut:

\section{Potensi dan Masalah}

Hasil prosedur pada tahap ini adalah hasil wawancara yang dilakukan kepada peserta didik dan guru matematika dari 3 Sekolah Menengah Atas yaitu MA Muhammadiyah Bandar Lampung, SMA AL-AZHAR 3 dan SMA Muhammadiyah 2 Bandar Lampung. Diketahui bahwa kebanyakan peserta didik tidak menyukai pelajaran matematika dan mengatakan bahwa matematika pelajaran yang sulit dipelajari. Bahan ajar yang digunakan di Sekolah tersebut adalah buku paket dan LKS. Bahan ajar yang digunakan hanya sebagai alat bantu untuk memberikan tugas karena bahan ajar yang tersedia belum menanamkan minat peserta didik secara mendalam, sehingga peserta didik masih kesulitan dalam memahami materi. Sehingga dengan bahan ajar yang dikembangkan diharapkan dapat membantu peserta didik dalam menyampaikan pelajaran, dan menjadikan peserta didik lebih aktif dalam proses pembelajaran.

\section{Pengumpulan Data}

Setelah proses potensi dan masalah selesai, maka tahap selanjutnya yaitu mengumpulkan informasi berupa apa yang menjadi keinginan dari peserta didik. Hasil dari wawancara diketahui peserta didik mengiginkan sebuah bahan ajar yang berbeda, bahan ajar yang menarik dan bisa membuat peserta didik 
lebih termotivasi dan lebih aktif dalam mengikuti proses pembelajaran.

\section{Desain Produk}

Hal yang dilakukan pada tahap ini desain produk adalah menentukan spesifikasi produk yang dikembangkan yaitu materi yang digunakan, indikator pencapaian kompetensi, tujuan pembelajaran, kegiatan percobaan atau pratikum yang memuat dalam materi trigonometri. Adapun langkah penyusunan modul ini adalah sebagai berikut:

\section{a. Bagian awal}

Pada bagian awal ini terdiri dari halaman depan (cover luar), cover dalam, kata pengantar, daftar isi, peta konsep, langkah pembelajaran PBL, glosarium, dan skema materi trigonometri.

b. Bagian isi Modul

Kegiatan percobaan sesuai dengan langkah PBL.

c. Bagian penutup

Pada bagian ini terdiri dari evaluasi, rangkuman, kunci jawaban, daftar pustaka dan cover belakang.

\section{Validasi Desain}

a. Validasi ahli materi

Hasil validasi ahli materi tahap 1 pada produk disajikan dalam bentuk tabel berikut:

\section{Tabel 4. Hasil validasi ahli materi tahap 1}

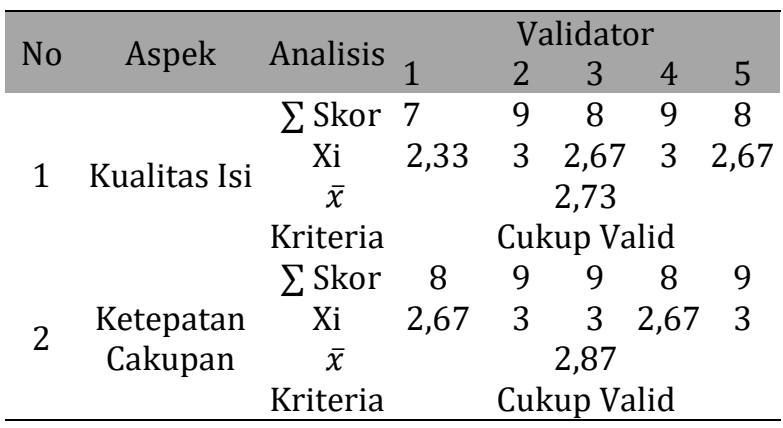

Berdasarkan validasi tahap 1 oleh ahli materi pada Tabel 4 diperoleh hasil penilaian dari 5 validator dapat diketahui bahwa validasi ahli materi memperoleh nilai, yaitu pada aspek kualitas isi diperoleh nilai rata-rata sebesar 2,73 dengan kriteria "cukup valid". Pada aspek ketepatan cakupan diperoleh nilai ratarata sebesar 2,87 dengan kriteria "cukup valid". Dengan demikian hasil dari penilaian ahli materi tahap 1 tersebut disimpulkan bahwa modul matematika yang dikembangkan dinyatakan dalam kriteria cukup valid dan perlu revisi kembali untuk masing-masing aspek sesuai saran yang diberikan.

b. Validasi ahli media

Hasil validasi ahli media tahap 1 pada produk disajikan dalam bentuk tabel berikut:

Tabel 5. Hasil validasi ahli media tahap 1

\begin{tabular}{|c|c|c|c|c|c|}
\hline \multirow{2}{*}{ No } & \multirow{2}{*}{ Aspek } & \multirow{2}{*}{ Analisis } & \multicolumn{3}{|c|}{ Validator } \\
\hline & & & 1 & 2 & 3 \\
\hline \multirow{5}{*}{1} & \multirow{5}{*}{ Ukuran Modul } & $\sum$ Skor & 6 & 7 & 6 \\
\hline & & $\mathrm{Xi}$ & 3 & 3,5 & 3 \\
\hline & & $\bar{x}$ & & 3,17 & \\
\hline & & Kriteria & $\mathrm{Cu}$ & kup V & lid \\
\hline & & $\sum$ Skor & 16 & 18 & 18 \\
\hline \multirow{3}{*}{2} & \multirow{3}{*}{$\begin{array}{l}\text { Desain Kulit } \\
\text { Modul }\end{array}$} & $\mathrm{Xi}$ & 2,67 & 3 & 3 \\
\hline & & $\bar{x}$ & & 2,89 & \\
\hline & & Kriteria & & kup V & \\
\hline \multirow{4}{*}{3} & \multirow{4}{*}{$\begin{array}{l}\text { Desain Isi } \\
\text { Modul }\end{array}$} & $\sum$ Skor & 33 & 33 & 34 \\
\hline & & $\mathrm{Xi}$ & 2,75 & 2,75 & 2,85 \\
\hline & & $\bar{x}$ & & 2,78 & \\
\hline & & Kriteria & & kup V & \\
\hline
\end{tabular}

Berdasarkan validasi tahap 1 oleh ahli media pada Tabel 5 diperoleh hasil penilaian dari 3 validator dapat diketahui bahwa validasi ahli media memperoleh nilai, yaitu pada aspek ukuran modul diperoleh nilai rata-rata sebesar 3,17 dengan kriteria "cukup valid". Pada aspek desain kulit modul diperoleh nilai ratarata sebesar 2,89 dengan kriteria "cukup valid". Pada aspek desain isi modul matematika diperoleh nilai rata-rata sebesar 2,78 dengan kriteria "cukup valid". Dengan demikian hasil dari penilaian ahli media tahap 1 tersebut disimpulkan bahwa modul matematika yang dikembangkan dinyatakan dalam kriteria cukup valid dan perlu revisi 
Desimal, 1 (2), 2018 - 222

Nia Anggraini, Rubhan Masykur

kembali untuk masing-masing aspek sesuai saran yang diberikan.

c. Validasi ahli bahasa

Hasil validasi ahli bahasatahap 1 pada produk disajikan dalam bentuk tabel berikut:

Tabel 6. Hasil validasi ahli bahasa tahap 1

\begin{tabular}{cccccc}
\multirow{2}{*}{ No } & \multirow{2}{*}{ Aspek } & Analisis & \multicolumn{3}{c}{ Validator } \\
& & S Skor & 26 & 2 & 3 \\
& & $\mathrm{Xi}$ & 2,89 & 2,78 & 32 \\
1 & \multirow{2}{*}{ Bahasa } & $\bar{x}$ & \multicolumn{3}{c}{3,07} \\
& & Kriteria & \multicolumn{3}{c}{ Cukup Valid } \\
\hline
\end{tabular}

Berdasarkan validasi tahap 1 pada Tabel 6 diperoleh hasil penilaian dari 3 validator dapat diketahui bahwa validasi ahli bahasa memperoleh nilai yaitu pada aspek bahasa diperoleh nilai rata-rata sebesar 3,07 dengan kriteria "cukup valid". Dengan demikian hasil dari penilaian ahli bahasa tahap 1 tersebut disimpulkan bahwa modul matematika yang dikembangkan dinyatakan dalam kriteria cukup valid dan perlu revisi kembali untuk masing-masing aspek sesuai saran yang diberikan.

\section{Perbaikan Desain}

a. Validasi dan Revisi oleh Ahli Materi

Adanya perbaikan gambar dalam materi yaitu penambahan nomor dan sudut $90^{\circ}$ pada gambar.Dengan demikian dari beberapa saran atau masukan yang diberikan oleh ahli materi telah diperbaiki.Tidak lanjut dari perbaikan menurut saran dan perbaikan dari ahli materi disajikan dalam Gambar 2.

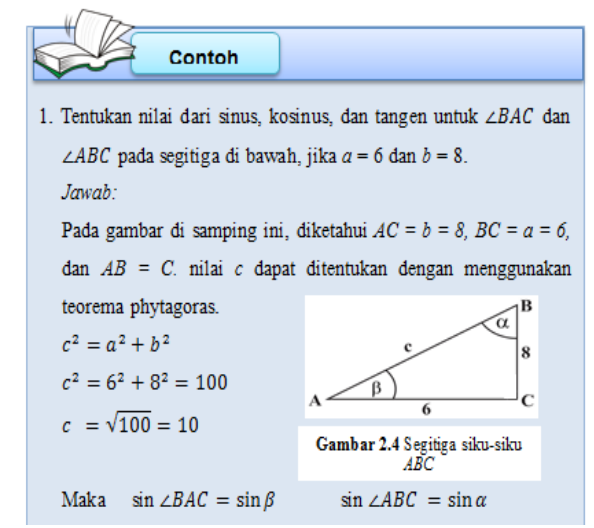

(a) Sebelum revisi

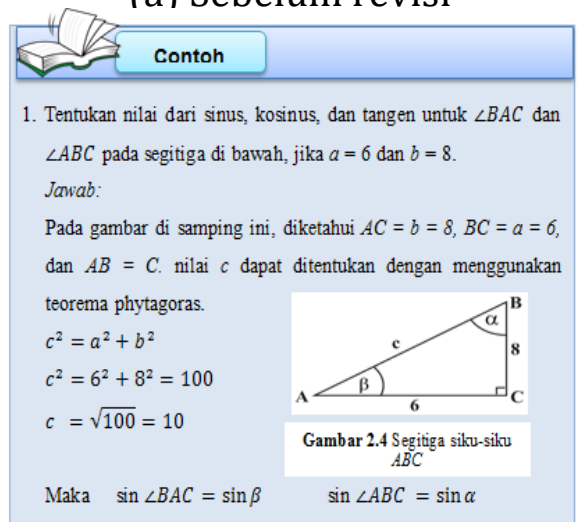

(b) Sesudah revisi

\section{Gambar 2 Penambahan sudut siku-siku} pada sudut $90^{\circ}$

Setelah produk direvisi berdasarkan saran atau masukan dari para validator, maka dilakukan validasi tahap kedua. Adapun umpan balik mengenai revisi yang telah dilakukan yaitu produk sudah mengalami perbaikan dan layak digunakan sehingga validasi kepada ahli materi sampai tahap kedua. Data hasil validasi tahap 2 oleh ahli materi dapat dilihat pada tabel berikut:

Tabel 7. Hasil validasi ahli materi tahap 2

\begin{tabular}{|c|c|c|c|c|c|c|}
\hline \multirow{2}{*}{ No } & \multirow{2}{*}{ Aspek } & \multirow{2}{*}{ Analisis } & \multicolumn{4}{|c|}{ Validator } \\
\hline & & & 1 & 23 & 4 & 5 \\
\hline \multirow{4}{*}{1} & \multirow{4}{*}{ Kualitas Isi } & $\sum$ Skor & 11 & $11 \quad 10$ & 10 & 11 \\
\hline & & Xi & 3,33 & $3,673,67$ & 3,33 & 3,67 \\
\hline & & $\bar{x}$ & & 3,53 & & \\
\hline & & Kriteria & & Valid & & \\
\hline \multirow{4}{*}{2} & & $\sum$ Skor & 10 & $11 \quad 11$ & 10 & 11 \\
\hline & Ketepatan & Xi & 3,33 & $3,673,67$ & 3,67 & 3,67 \\
\hline & Cakupan & $\bar{x}$ & & 3,53 & & \\
\hline & & Kriteria & & Valid & & \\
\hline
\end{tabular}


Desimal, 1 (2), 2018 - 223

Nia Anggraini, Rubhan Masykur

Berdasarkan validasi tahap 2 oleh ahli materi pada Tabel 7 diperoleh hasil penilaian dari 3 validator dapat diketahui bahwa validasi ahli materi memperoleh nilai, yaitu pada aspek kualitas isi diperoleh nilai rata-rata sebesar 3,53 dengan kriteria "valid". Pada aspek ketepatan cakupan diperoleh nilai ratarata sebesar 3,53 dengan kriteria "valid". Dengan demikian hasil dari penilaian ahli materi tahap 2 tersebut disimpulkan bahwa modul matematika yang dikembangkan dinyatakan dalam kriteria valid dan tidak perlu direvisi kembali.

b. Validasi dari Revisi oleh Ahli Media

Adanya perbaikan caper depan dan belakang. Dengan demikian dari beberapa saran atau masukan yang diberikan oleh ahli materi telah diperbaiki.Tidak lanjut dari perbaikan menurut saran dan perbaikan dari ahli media disajikan dalam gambar 3.

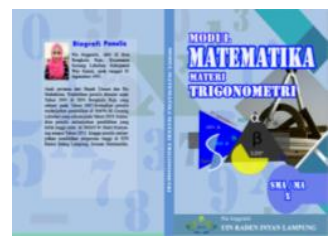

(a) Sebelum Revisi

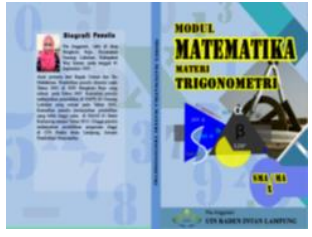

(b) Sesudah revisi

\section{Gambar 3 Perbaikan Cover Modul Matematika}

Setelah produk direvisi berdasarkan saran atau masukan dari para validator, maka dilakukan validasi tahap kedua. Adapun umpan balik mengenai revisi yang telah dilakukan yaitu produk sudah mengalami perbaikan dan layak digunakan sehingga validasi kepada ahli mediasampai tahap kedua.Data hasil validasi tahap 2 oleh ahli mediadapat dilihat pada tabel berikut:
Tabel 8. Hasil validasi ahli media tahap 2

\begin{tabular}{cccccc}
\hline \multirow{2}{*}{ No } & \multirow{2}{*}{ Aspek } & Analisis & \multicolumn{3}{c}{ Validator } \\
& & & 2 & 3 \\
& & S Skor & 7 & 7 & 8 \\
1 & Ukuran Modul & Xi & 3,5 & 3,5 & 4 \\
& & $\bar{x}$ & & 3,67 & \\
& & Kriteria & \multicolumn{3}{c}{ Valid } \\
& & $\sum$ Skor & 22 & 21 & 22 \\
2 & Desain Kulit & Xi & 3,67 & 3,5 & 3,67 \\
& Modul & $\bar{x}$ & \multicolumn{3}{c}{3,61} \\
& & Kriteria & \multicolumn{3}{c}{ Valid } \\
& & $\sum$ Skor & 41 & 41 & 42 \\
3 & Desain Isi & Xi & 3,42 & 3,42 & 3,5 \\
& Modul & $\bar{x}$ & \multicolumn{3}{c}{3,44} \\
& & Kriteria & \multicolumn{3}{c}{ Valid } \\
\hline
\end{tabular}

Berdasarkan validasi tahap 2 oleh ahli media pada Tabel 8 diperoleh hasil penilaian dari 3 validator dapat diketahui bahwa validasi ahli media memperoleh nilai, yaitu pada aspek ukuran modul diperoleh nilai rata-rata sebesar 3,67 dengan kriteria "valid". Pada aspek desain kulit modul diperoleh nilai rata-rata sebesar 3,61 dengan kriteria "valid". Pada aspek desain isi modul diperoleh nilai rata-rata sebesar 3,44 dengan kriteria "valid".Dengan demikian hasil dari penilaian ahli media tahap 2 tersebut disimpulkan bahwa modul matematika yang dikembangkan dinyatakan dalam kriteria valid dan tidak perlu direvisi kembali.

\section{c. Validasi dari Revisi oleh Ahli Bahasa}

Adanya perbaikan pada penggunaan bahasa baku. Dengan demikian dari beberapa saran atau masukan yang diberikan oleh ahli bahasa telah diperbaiki.Tidak lanjut dari perbaikan menurut saran dan perbaikan dari ahli materi disajikan dalam Gambar 4. 
Desimal, 1 (2), 2018 - 224

Nia Anggraini, Rubhan Masykur

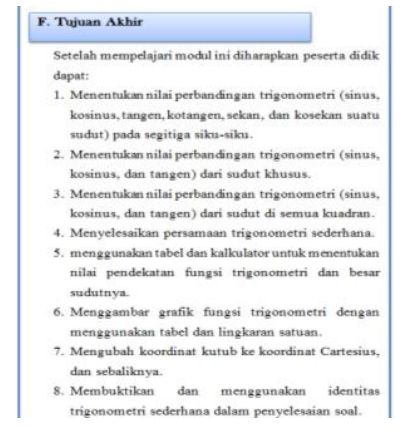

(a) Sebelum revisi

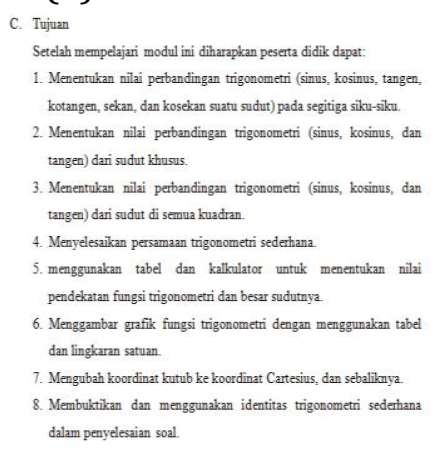

(b) Setelah revisi

\section{Gambar 4 Penggunaan Bahasa Baku}

Setelah produk direvisi berdasarkan saran atau masukan dari para validator, maka dilakukan validasi tahap kedua.Adapun umpan balik mengenai revisi yang telah dilakukan yaitu produk sudah mengalami perbaikan dan layak digunakan sehingga validasi kepada ahli bahasa sampai tahap kedua.Data hasil validasi tahap 2 oleh ahli materi dapat dilihat pada tabel berikut:

\section{Tabel 9. Hasil validasi ahli bahasa tahap 2}

\begin{tabular}{|c|c|c|c|c|c|}
\hline \multirow{2}{*}{ No } & \multirow{2}{*}{ Aspek } & \multirow{2}{*}{ Analisis } & \multicolumn{3}{|c|}{ Validator } \\
\hline & & & 1 & 2 & 3 \\
\hline \multirow{4}{*}{1} & \multirow{4}{*}{ Bahasa } & $\sum$ Skor & 27 & 34 & 33 \\
\hline & & $\mathrm{Xi}$ & 3 & 3,78 & 3,67 \\
\hline & & $\bar{x}$ & & 3,48 & \\
\hline & & Kriteria & & Valid & \\
\hline
\end{tabular}

Berdasarkan validasi tahap 2 pada Tabel 9 diperoleh hasil penilaian dari 3 validator dapat diketahui bahwa validasi ahli bahasa memperoleh nilai, yaitu pada aspek bahasa diperoleh nilai rata-rata sebesar 3,48 dengan kriteria "valid".Dengan demikian hasil dari penilaian ahli bahasa tahap 2 tersebut disimpulkan bahwa modul matematika yang dikembangkan dinyatakan dalam kriteria valid dan tidak perlu direvisi kembali.

\section{Uji Coba Produk}

a. Uji Kelompok Kecil

Uji coba kelompok kecil terdiri atas 10 peserta didik diambil secara acak.Pada uji ini peserta didik diminta untuk mengisi angket kemenarikan modul matematika yang dikembangkan.Instrumen penilaian yang dinilai oleh peserta didik memiliki kriteria yang dapat dilihat pada tabel 10 .

Tabel 10. Hasil uji kelompok kecil

\begin{tabular}{clcc}
\multirow{2}{*}{ No } & Nama Sekolah & \multicolumn{2}{c}{ Hasil Analisis } \\
& & $\bar{x}$ & Kriteria \\
1 & MA Muhammadiyah & 3,13 & Menarik \\
& Bandar Lampung & & \\
2 & SMA AL-AZHAR 3 & 2,9 & Menarik \\
3 & SMA Muhammadiyah 2 & 3,14 & Menarik \\
& Bandar Lampung & & \\
\hline
\end{tabular}

Berdasarkan Tabel 10 di atas dapat bahwa tingkat kemenarikan modul matematika berdasarkan model pembelajaran PBL pokok materi trigonometri dengan uji coba kelompok kecil di MA Muhammadiyah Bandar Lampung dengan skor rata-rata 3,13, SMA AL-AZHAR 3 dengan skor rata-rata 2,19 dan SMA Muhammadiyah 2 Bandar Lampung dengan skor rata-rata 3,14 termasuk pada kategori menarik.

\section{b. Uji Coba Lapangan}

Setelah uji kelompok kecil tahap selanjutnya adalah uji coba lapangan terdiri dari 30 peserta didik diambil secara acak.Peserta didik diminta untuk mengisi angket kemenarikan modul matematika yang dikembangkan.Instrumen penilaian yang dinilai oleh peserta didik memiliki kriteria yang dapat dilihat pada Tabel 11 . 
Tabel 11. Hasil uji coba lapangan

\begin{tabular}{|c|c|c|c|}
\hline \multirow[t]{2}{*}{ No } & \multirow[t]{2}{*}{ Nama Sekolah } & \multicolumn{2}{|c|}{ Hasil Analisis } \\
\hline & & $\bar{x}$ & Kriteria \\
\hline 1 & MA Muhammadiyah & 3,65 & \\
\hline 2 & SMA AL-AZHAR 3 & 3,55 & $\begin{array}{l}\text { Sangat } \\
\text { Menarik }\end{array}$ \\
\hline 3 & $\begin{array}{l}\text { SMA Muhammadiyah } 2 \\
\text { Bandar Lampung }\end{array}$ & 3,53 & $\begin{array}{l}\text { Sangat } \\
\text { Menarik }\end{array}$ \\
\hline
\end{tabular}

Berdasarkan Tabel 11 didapat bahwa tingkat kemenarikan modul matematika berdasarkan model pembelajaran PBL pokok materi trigonometri dengan uji coba kelompok kecil di MA Muhammadiyah Bandar Lampung dengan skor rata-rata 3,65, SMA AL-AZHAR 3 dengan skor rata-rata 3,55 dan SMA Muhammadiyah 2 Bandar Lampung dengan skor rata-rata 3,53 termasuk pada kategori sangat menarik.

\section{Revisi Produk}

Setelah dilakukan uji coba kelompok kecil dan uji coba lapangan untuk mengetahui kemenarikan modul matematika berdasarkan model pembelajaran PBL pokok materi trigonometri, produk dikatakan kemenarikannya sangat tinggi sehingga tidak dilakukan uji coba ulang. Selanjutnya modul matematika dapat dimanfaatkan sebagai salah satu sumber belajar bagi peserta didik dan pendidik di SMA/MA pada materi trigonometri untuk kelas X.

Pemakaian bahan ajar bisa meningkatakan rasa penasaran siswa tinggi, menciptakan semangat baru, bahkan berdampak baik terhadap siswa (Sari, Farida, \& Syazali, 2016). Secara lebih lanjut penggunaan media pembelajaran memberikan perasaan senang bagi peserta didik (Nurwani, Rizki Wahyu Yunian Putra, Fredi Ganda Putra, 2017). Pengembangan media sangat penting artinya untuk meminimalisir kekurangan dan keterbatasan yang sudah ada. Penggunaan media berupa modul dapat membantu peserta didik dalam mengembangkan konsep, melatih peserta didik dalam menemukan dan mengembangkan keterampilan proses pembelajaran, serta membantu peserta didik memperoleh catatan tentang materi yang dipelajari melalui kegiatan belajar secara sistematis. Media pembelajaran dinilai dapat meningkatkan mutu pendidikan (Sari et al., 2016)

Hasil penelitian yang dilakukan oleh Sudi Dul Aji, M Nur Hudha, dan Astri Yuni $\mathrm{R}$ menyatakan bahwa Modul pembelajaran fisika berbasis PBL pada topik keseimbangan dan dinamika rotasi dapat meningkatkan kemampuan pemecahan masalah fisika siswa SMA. Hal ini dapat diketahui dengan penilaian ahli materi dan guru fisika pada komponen kelayakan isi, yaitu permasalahan yang disajikan dapat meningkatkan kemampuan pemecahan masalah peserta didik yang memperoleh presentase sebesar 91,7 \% (Aji, Hudha, \& Rismawati, 2017).

Hasil Penelitian yang dilakukan oleh Rizky Wahyu Yunian Putra dan Rully Anggraini menyatakan bahwa pengembangan bahan ajar materi trigonometri berbantuan software ImindMap dapat memudahkan peserta didik dalam mengingat pelajaran trigonometri (Putra \& Anggraini, 2016). Sesuai dengan penelitian yang dilakukan oleh(Ismail, Jamil, \& Putri, 2017)Menyatakan bahwa Modul Trigonometri bercirikan open-ended problem yang dikembangkan mendapatkan respon posisitif dari mahasiswa.Hal tersebut dapat terlihat dari adanya peningkatan nilai dari hasil tes pada observasi awal dengan hasil tes mahasiswa setelah pelaksanaan uji coba modul. Terdapat peningkatan 32\% mahasiswa yang menjawab benar dalam menjawab masalah dengan cara bervariasi. Peningkatan mahasiswa yang menjawab benar dalam menjawab masalah dengan jawaban bervariasi sebesar $62 \%$. Sedangkan peningkatan mahasiswa dalam menyusun soal dengan 
mengubah masalah yang diberikan sebelumnya serta menyelesaikannya sebesar 44\%.

Hasil Penelitian yang dilakukan oleh Nurashri, Adelina Hasyin, dan Sugeng Sutiarso menyatakan bahwa LKS trigonometri memperoleh hasil positif dari peserta didik sebagai berikut:kelas eksperimen sebesar 30,91\% pada SMA Gajah Mada, $14,14 \%$ pada SMA Muhamadiyah, dan 11,63\% pada SMA Al Azhar (Partasiwi, Hasyim, \& Sutiarso, 2017)

Sesuai dengan hasil penelitian penulis dalam pengembangan modul matematika berdasarkan model pembelajaran PBL memperoleh hasil yang baik dari peserta didik dan para ahli sebagai berikut: Hasil validasi ahli materi pada aspek kualitas isi memperoleh ratarata skor 3,53 dengan kriteria valid, pada aspek ketepatan cakupan memperoleh rata-rata skor 3,53 dengan kriteria valid. Validasi ahli media pada aspek ukuran Modul memperoleh rata-rata skor 3,67 dengan kriteria valid, aspek desain kulit Modul memperoleh rata-rata skor 3,61 dengan kriteria valid dan pada aspek desain isi Modul memperoleh rata-rata skor 3,44 dengan kriteria valid. Validasi ahli bahasa pada aspek bahasa memperoleh rata-rata skor 3,48 dengan kriteria valid. Angket respon peserta didik memperoleh nilai rata-rata 3,58 kriteria sangat menarik.

Perbedaan penelitian ini dengan penelitian sebelumnya adalah pada modul matematika yang dikembangkan dituangkan dalam langkah-langkah PBL, contoh masalah yang ada pada modul ini terintegrasi oleh nilai-nilai islami. Sistematika modul matematika yang disajikan secara berurut, yaitu bagian awal, bagian isi dan bagian penutup. Pada bagian awal ini terdiri dari halaman depan (cover luar), cover dalam, kata pengantar, daftar isi, peta konsep, langkah pembelajaran PBL, glosarium, dan skema materi trigonometri. Pada bagian isi terdapat materi trigonometri dan soal-soal kegiatan peserta didik dengan langkah PBL.Serta pada bagian penutup terdiri dari evaluasi, rangkuman, kunci jawaban, daftar pustaka dan cover belakang.

Modul ini diharapkan bisa membantu kemampuan peserta didik dalam memprediksi, mengamati dan menjelaskan, membantu peserta didik dalam proses pembelajaran dengan aktif sehingga peserta didik ada kemauan untuk mencoba sendiri dalam setiap pengerjaan soal dan memahami materi. Hal ini sesuai dengan kelebihan PBL bahwa dengan pemecahan masalah dapat mengembangkan pengetahuan peserta didik untuk berpikir kritis, inovatif, dan memotivasi peserta didik untuk belajar dan mengembangkan kemampuan yang ada pada dirinya.

\section{Kelebihan dan kekurangan produk hasil pengembangan}

Produk pengembangan ini memiliki beberapa kelebihan sebagai berikut ini:

(1) Modul matematika yang dikembangkan memberikan wawasan pengetahuan baru kepada peserta didik, baik dalam segi materi matematika maupun keterkaitan antara materi trigonometri dengan kehidupan seharihari. (2) Modul matematika ini memuat materi trigonometri yang disusun dengan langkah model pembelajaran PBLyang mengharuskan peserta didik bisa sampai tahap C6 (Evaluasi).

Produk hasil pengembangan ini memiliki beberapa kekurangan sebagai berikut ini:

(1) Pengembangan modul matematika ini belum sampai pada tahap uji coba pemakaian sehingga belum bisa dilihat seberapa besar tingkat keefektivitasannya. (2) Modul matematika ini masih terbatas pada materi trigonometri dalam bentuk cetakan dan belum tersedia secara online sehingga belum bisa digunakan secara 
luas untuk peserta didik maupun pendidik diberbagai sekolah.

\section{SIMPULAN DAN SARAN}

Modul matematika berdasarkan model pembelajaran PBL materi pokok trigonometri ini telah dikembangkan dengan menggunakan 7 tahapan yaitu potensi dan masalah, pengumpulan data, desain produk, validasi produk, revisi produk, uji coba produk dan revisi produk. Hasil validasi ahli materi pada aspek kualitas isi memperoleh rata-rata skor 3,53 dengan kriteria valid, pada aspek ketepatan cakupan memperoleh rata-rata skor 3,53 dengan kriteria valid. Validasi ahli media pada aspek ukuran Modul memperoleh rata-rata skor 3,67 dengan kriteria valid, aspek desain kulit Modul memperoleh rata-rata skor 3,61 dengan kriteria valid dan pada aspek desain isi Modul memperoleh rata-rata skor 3,44 dengan kriteria valid. Validasi ahli bahasa pada aspek bahasa memperoleh rata-rata skor 3,48 dengan kriteria valid. Respon peserta didik terhadap modul matematika di MA Muhammadiyah Bandar Lampung, di SMA AL-AZHAR 3, dan di SMA Muhammadiyah 2 Bandar Lampung memperoleh skor rata-rata sebesar 3,58 dengan kriteria sangat menarik.

Beberapa saran yang dapat diberikan untuk modul matematika ini yaitu sebagai berikut:

(1) Modul matematika berdasarkan model pembelajaran PBL hanya menyajikan materi trigonometri sehingga diharapkan untuk penulis selanjutnya dapat mengembangkan modul matematika dengan materi yang lebih luas. (2) Penggunaan modul matematika berdasarkan model pembelajaran PBL ini melalui tahap-tahap metode ilmiah, guru perlu membuat suatu panduan tertulis tentang langkah-langkah PBL sehingga dengan panduan tersebut guru akan lebih mudah mensosialisasikan kepada peserta didik.

\section{DAFTAR PUSTAKA}

Aji, S., Hudha, M. N., \& Rismawati, A. (2017). Pengembangan Modul Pembelajaran Fisika Berbasis Problem Based Learning untuk Meningkatkan Kemampuan Pemecahan Masalah Fisika. SEJ (Science Education Journal), 1(1), 3651.

https://doi.org/10.21070/sej.v1i1.8 30

Citroresmi, N., Sugiatno, S., \& Suratman, D. (2016). Pengembangan Modul Matematika Berbasis Masalah untuk Meningkatkan Kemampuan Penyelesaian Masalah dan Berpikir Kreatif Matematis Siswa. Jurnal Pendidikan Dan Pembelajaran, 5(4).

Ismail, A. D., Jamil, A. F., \& Putri, O. R. U. (2017). Pengembangan Modul Trigonometri Bercirikan OpenEnded Problem. AdMathEdu: Jurnal Ilmiah Pendidikan Matematika, Ilmu Matematika Dan Matematika Terapan, 7(1), 1-8.

Khayati, F., Sujadi, I., \& Sari Suprapto, R. (2016). Pengembangan Modul Matematika untuk Pembelajaran Berbasis Masalah (Poblem Based Learning) pada Materi Pokok Persamaan Garis Lurus Kelas VIII SMP. Jurnal Elektronik Pembelajaran Matematika, 4(7), 613-618.

Nurhayati, F., Widodo, J., \& Soesilowati, E. (2015). Pengembangan LKS Berbasis Problem Based Learning (PBL) Pokok Bahasan Tahap Pencatatan Akutansi Perusahaan Jasa. Journal of Economic Education, 4(1), 14-19.

Nurwani, Rizki Wahyu Yunian Putra, Fredi Ganda Putra, N. W. P. (2017). Pengembangan Desain Didaktis Bahan Ajar Materi Pemfaktoran Bentuk Aljabar pada Pembelajaran Matematika SMP. Numerical, 1(2), 193-206.

Partasiwi, N., Hasyim, A., \& Sutiarso, S. (2017). Pengembangan Lembar Kerja Siswa Trigonometri Dengan 
Desimal, 1 (2), 2018 - 228

Nia Anggraini, Rubhan Masykur

Model Problem Based Learning. Jurnal Teknologi Informasi Komunikasi Pendidikan (Old), 5(1).

Putra, R. W. Y., \& Anggraini, R. (2016). Pengembangan Bahan Ajar Materi Trigonometri Berbantuan Software iMindMap pada Siswa SMA. Al-Jabar : Jurnal Pendidikan Matematika, 7(1), 39-47.

Rhosyida, N., \& Jailani, J. (2014). Pengembangan Modul Matematika SMK Bidang Seni, Kerajinan, dan Pariwisata Berbasis Open-Ended Problem sebagai Implementasi KTSP. Jurnal Riset Pendidikan Matematika, 1(1), 35-47.

Sari, F. K., Farida, F., \& Syazali, M. (2016). Pengembangan Media Pembelajaran (Modul) berbantuan Geogebra Pokok Bahasan Turunan. Al-Jabar: Jurnal Pendidikan Matematika, 7(2), 135151.

Semadiartha, I. kadek S. (2012). Pengembangan Media Pembelajaran Berbasis Komputer dengan Microsoft Excel yang Berorientasi Teori Van Hiele pada Bahasan Trigonometri Kelas X SMA untuk Meningkatkan
Prestasi dan Motivasi Belajar Matematika Siswa. Universitas Pendidikan Ganesha.

Sugiyono, M. (2012). Metode Penelitian Kuantitatif, Kualitatif, dan Kombinasi. Bandung: Alfabeta.

Sulistyaningrum, Karyanto, P., \& Sunarno. (2015). Pengembangan Modul Berbasis Model Pembelajaran Arias untuk Memberdayakan Motivasi dan Berfikir Kritis Siswa pada Materi Ekosistem. INKUIRI Jurnal, 1(4), 116.

Syahrir, S., \& Susilawati, S. (2015). Pengembangan Modul Pembelajaran Matematika Siswa SMP. Jurnal Ilmiah Mandala Education (JIME), 1(2), 162-171.

Syarifah, S. (2017). Pengembangan LKPD Berorientasi Nilai-nilai Islam Melalui Pendekatan Inkuiri Terbimbing Materi Trigonometri. Lampung.

Wenno, I. H. (2010). Pengembangan Modul IPA Berbasis Problem Solving Method Berdasarkan Karakteristik Siswa dalam Pembelajaran di SMP/MTs. Cakrawala Pendidikan, 2(2), 176-188. 